\title{
Musik Panting di Desa Barikin Kalimantan Selatan: Kemunculan, Keberadaan dan Perubahannya
}

\author{
Lupi Anderiani ${ }^{1}$
}

Program Pascasarjana Institut Seni Indonesia Surakarta

\begin{abstract}
ABSTRAK
Panting merupakan sebuah praktik musik yang berasal dari Kalimantan Selatan, Indonesia. Istilah "Panting" memiliki dua arti, yakni, pertama, sebagai nama sebuah instrumen berdawai yang dimainkan dengan cara dipetik; dan, kedua, nama dari sebuah ansambel musik. Musik Panting muncul sekitar tahun 1980-an. Penelitian ini menggunakan pendekatan etnomusikologis dengan menekankan pada kerja lapangan, bertujuan untuk menelaah kemunculan dan perubahan musik Panting. Berdasarkan analisis, terlihat bahwa musik Panting terutama muncul sebagai hasil laku kreatif seniman pelopornya dalam menanggapi praktik-praktik musik yang sudah ada. Dalam perjalanannya musik ini mengalami sejumlah perubahan, yakni dalam hal fungsi musik, bentuk penyajian, konstruksi instrumen, dan pola transmisi. Perubahan ini terutama disebabkan oleh keinginan personal para musisinya dan juga kondisi lingkungan kultural yang memungkinkan.
\end{abstract}

Kata kunci: Panting, musik Borneo, Barikin

\begin{abstract}
The Model of Music Learning through a Lesson Study: A Case Study in Jawilan Elementary School, Serang. The learning problems of music lessons at Jawilan Elementary School in Serang becomes the mainly source of the research background in this article. The implementation of art education in this school has not gained enough attention from teachers. It can be seen from the distribution of the allocated time of learning and the involvement of classroom teachers who do not have sufficient background in art education (music). The appearing impact shows that the average of students do not have any independence in creativity and have less-active participation in the activities of musical arts either in school or outside the school. However, solving the problem is necessary to do by using a Lesson Study as a pattern (approaches, strategies, and methods of learning) to teach music that can be used as an alternative point of view in developing methods and organizing the appropriate ones, including the paradigm of teaching music at school essentially. The results obtained from the activity may provide the alternative method as a basis for the development of learning music at school.
\end{abstract}

Keywords: music learning, Elementary School, Lesson Study

\section{Pendahuluan}

Secara kultural, Kalimantan Selatan merupakan wilayah yang heterogen karena didiami oleh lebih dari satu suku-bangsa, yakni Melayu, Dayak, Jawa, Madura, Bugis, Cina dan Arab. Namun demikian, penduduk mayoritas di Kalimantan Selatan adalah Melayu dan Dayak. Di daerah ini, suku-bangsa Melayu biasa disebut dengan Suku Banjar, sedangkan kelompok yang mendiami wilayah pedalaman, yakni orang Dayak, lazim disebut dengan Urang Bukit. Oleh masyarakat setempat, Banjar dan Dayak dianggap sebagai sukubangsa asli Kalimantan Selatan (Radam, 2001: 95).

Kata "Banjar" konon berasal dari Banjarmasih, yang dulunya merupakan nama sebuah kampung

\footnotetext{
Alamat korespondensi: Prodi Pengkajian dan Penciptaan Seni, PPS ISI Surakarta. Jln Ki Hajar Dewantara, Kentingan, Surakarta. Email: lupianderiani@gmail.com
} 
suku-bangsa Melayu yang terletak di muara Sungai Kuwin, salah satu anak Sungai Barito. Banjarmasih sendiri terbentuk dari dua kata, yakni "Banjar", yang berarti kampung; dan "Masih", yakni nama seorang kepala suku Melayu atau Patih-orang Dayak Ngaju menyebut kepala suku Melayu ini, yakni Patih Masih, sebagai Oloh Masih. Versi lain menyebutkan bahwa kata "Banjar" berarti berderet-deret, yakni deretan perumahan, kampung, pedukuhan atau desa di atas air, di sepanjang tepi sungai. Nama Banjarmasih lambat laun berubah pelafalannya menjadi Banjarmasin karena pengucapan orang Belanda (Saleh, 1981/82: 2).

Suku-bangsa Melayu konon sudah mendiami wilayah ini jauh sebelum masuknya agama Islam dan sebelum berdirinya Kerajaan Banjar. Mereka hidup berdampingan dengan suku-bangsa Dayak. Seiring berjalannya waktu, suku-bangsa Banjar, dengan identitas keislamannya, terbagi ke dalam tiga kelompok besar, yaitu suku-bangsa Banjar Kula, yang mendiami wilayah Banjarmasin dan Martapura; suku-bangsa Banjar Batang Banyu, yang mendiami wilayah tepian Sungai Tabalong hingga ke Kelua; dan suku-bangsa Banjar Hulu (Pahuluan), yang mendiami daerah kaki Pegunungan Meratus, mulai dari Tanjung hingga ke Pelaihari. Ketiga kelompok besar ini memiliki ciri khas masing-masing, terutama dalam hal dialek bahasanya (Radam, 2001: 95).

Suku-bangsa lain yang dianggap sebagai penduduk asli di Kalimantan Selatan, yakni Dayak atau yang juga disebut Urang Bukit, mendiami wilayah kaki Pegunungan Meratus. Menurut Mallinckrodt, seperti yang dikutip dalam Radam (2001: 95), mereka merupakan pecahan atau salah satu puak suku-bangsa Ma'anyan yang sebagian besar menyerap unsur-unsur kebudayaan melayu, terutama dalam hal bahasa. Dalam bahasa Banjar, kata "bukit" memiliki dua pengertian: pertama, berarti ketertinggalan dalam hal peradaban, biasanya digunakan untuk menyebut suatu kelompok masyarakat atau individu; kedua, berarti gunung kecil atau anak gunung.

Pada awalnya, masyarakat yang mendiami daerah Kalimantan Selatan adalah Dayak Maanyatn. Suku-bangsa ini mendirikan sebuah kerajaan, yakni Nan Sarunai, yang diperkirakan terletak di wilayah Hulu Sungai Utara. Setelah itu, datang lah orang-orang Melayu pertama, yang kemudian mendirikan kerajaan bernama Tanjung Puri. Kerajaan Tanjung Puri diperkirakan terletak di daerah Tabalong, yang sekarang wilayahnya dikenal dengan nama Kota Tanjung (Idham dkk., 2005: 11-12). Orang Melayu dan Dayak menjalin hubungan yang harmonis dan hidup berdampingan. Orang-orang Melayu pertama ini kelak terdesak ke daerah Pegunungan Meratus (dan menjadi cikal bakal Orang Bukit) oleh Orang Melayu yang datang belakangan. Setelah itu, datang para imigran dari Pulau Jawa, yang kemudian membangun kerajaan di daerah pertemuan antara Sungai Amandit dan Sungai Nagara. Ketiga kelompok masyarakat ini tentu datang dengan membawa serta kebudayaannya masing-masing. Ketiga kebudayaan inilah yang kemudian membaur, memunculkan satu kebudayaan baru, yakni kebudayaan Banjar (Idham dkk., 2005: 12-14).

Keanekaragaman suku-bangsa di Kalimantan Selatan antara lain juga berdampak pada keragaman keseniannya. Akulturasi kebudayaan asli dengan pendatang memunculkan sebuah kebudayaan yang dapat disebut baru, yang hidup dan mampu bertahan hingga saat ini. Banyak terdapat jenis kesenian di Kalimantan Selatan, mulai dari musik tradisi, tari hingga teater rakyat, yang berasal dari suku bangsa yang ada di wilayah ini. Kendati demikian, kesenian rakyat yang cukup menonjol di Kalimantan Selatan adalah yang berasal dari suku Banjar. Selain kesenian Melayu, Suku Banjar juga memiliki kesenian yang mendapat pengaruh dari Jawa dan sudah ada sejak zaman kerajaan di Kalimantan Selatan, misalnya gamelan Banjar, wayang kulit, wayang orang, wayang gong, dan tarian klasik peninggalan Keraton Banjar. Salah satu kesenian rakyat yang cukup dikenal di wilayah Kalimantan Selatan hingga saat ini adalah musik Panting yang berakar dari musik Melayu.

Musik Panting merupakan kesenian asli Kalimantan Selatan hasil karya cipta, dan berkembang di dalam masyarakat suku Banjar (Bakhtiar Sanderta, Komunikasi Pribadi). Kini, kesenian ini masih sering dipergelarkan oleh masyarakat, baik di pedesaan maupun di perkotaan. 
Bahkan, musik ini juga kerap diundang sampai ke luar daerah, misalnya Kalimantan Tengah, Kalimantan Timur, Tembilahan (daerah Kepulauan Riau), dan Pulau Jawa. Beberapa grup musik Panting juga tidak jarang mendapat undangan untuk bertandang ke negeri jiran Malaysia guna menghibur masyarakat Banjar yang ada di sana. Musik Panting tidak hanya ditampilkan dalam acara yang digelar oleh masyarakat saja, melainkan juga dalam kegiatan resmi yang melibatkan para pejabat.

Kemunculan musik ini dipelopori oleh masyarakat Desa Barikin, Kecamatan Haruyan, Kabupaten Hulu Sungai Tengah, Kalimantan Selatatan Timur (Bakhtiar Sanderta, Komunikasi Pribadi). Masyarakat Barikin kemudian mengembangkan dan menyebarkan musik Panting ke wilayah lain di Kalimantan Selatan dan daerah-daerah lainnya, termasuk Kalimantan Tengah dan Kalimantan Timur. Musik Panting di Desa Barikin cukup termahsyur di kalangan masyarakat Kalimantan Selatan, sehingga banyak orang datang ke desa ini untuk mempelajarinya. Bahkan, beberapa grup musik Panting yang ada di Kalimantan Selatan merupakan binaan dari Desa Barikin. Desa Barikin memang cukup dikenal di wilayah Kalimantan Selatan karena potensi keseniannya, bahkan sebelum lahirnya musik Panting. Potensi seni dan budaya yang dimiliki oleh desa ini merupakan warisan turun temurun dari leluhur mereka dan masih dilestarikan hingga saat ini.

Terlepas dari kemahsyurannya di kalangan masyarakat, sejauh ini belum ada literatur yang membahas secara cukup mendalam tentang musik Panting. Kemunculan musik Panting merupakan fenomena yang menarik untuk dilihat lebih dekat: Bagaimana kemunculannya? Bagaimana kehidupan atau keberadaannya? Apakah ia mengalami perubahan dalam keberadaannya? Melalui penelitian ini, penulis mencoba menelaah kemunculan, keberadaan dan perubahan yang dialami oleh musik Panting.

Penelitian ini menggunakan pendekatan etnomusikologis yang menekankan pada kerja lapangan. Data mengenai musik Panting nyaris seluruhnya bersifat lisan, masih berada di "kepala" para pelaku dan informan, sehingga cara utama untuk menggali dan mengumpulkannya adalah dengan melakukan wawancara dan observasi. Para informan adalah mereka yang terlibat atau bersinggungan langsung dengan musik Panting sejak awal kemuculannnya hingga saat ini, termasuk pelopornya. Selain wawancara dan observasi, terutama untuk data-data yang bersifat historis, digali dengan studi literatur. Secara garis besar, data yang dikumpulkan berfokus pada proses kemunculan, keberadaan dan perubahan musik Panting sejak awal kemunculanya, yakni tahun 1980-an hingga saat ini.

\section{Hasil dan Pembahasan}

\section{Musik Panting}

Istilah "Panting" memiliki dua arti: pertama, Panting merupakan nama instrumen musik jenis kordofon yang berasal dari instrumen kecapi Dayak yang kemudian mendapat pengaruh dari gambus Melayu. Bentuk instrumen Panting sangat identik dengan gambus yang tersebar luas di Alam Melayu. Sebutan Panting diambil dari teknik memainkan instrumen tersebut, yakni dipetik-dipetik, dalam bahasa Banjar Hulu, adalah di-panting. Instrumen Panting hanya digunakan oleh masyarakat Banjar Hulu, sementara masyarakat Banjar wilayah pesisir menggunakan instrumen gambus Melayu. Kedua, Panting merupakan nama dari sebuah ansambel musik, dengan instrumen Panting sebagai instrumen utamanya, selain juga instrumen suling, biola, babun (sejenis kendang), kampul (sejenis kempul), agung basar (sejenis gong suwuk), kaprak atau marawis, kulimpat(sejenis ketipung), dan kicik (tamborin). Tangga nada yang digunakan mendekati atau sangat serupa dengan tangga nada diatonis.

\section{Kemunculan Musik Panting di Desa Barikin}

\section{a. Barikin sebagai Basis Seni Tradisional Kalimantan Selatan}

Desa Barikin memiliki potensi seni dan budaya yang terbilang besar dalam lingkup wilayah Kalimantan Selatan. Ini antara lain terlihat dari masih adanya sejumlah seni 
pertunjukan rakyat dan juga kesenian klasik peninggalan Keraton Banjar di desa ini. Jika ada riset yang berkaitan dengan seni dan budaya yang ada di Kalimantan Selatan, pemerintah setempat seringkali mengarahkan para peneliti untuk datang ke Barikin. Barikin dijadikan sebagai rujukan. Salah satu tokoh seni lokal-tradisional yang membina, melestarikan dan mengembangkan seni lokal adalah A. W. Syarbaini (1955-2016).

Mayoritas seni tradisional yang ada di daerah Kalimantan Selatan, khususnya seni pertunjukan, memang terdapat di Desa Barikin. Bahkan, ada sejumlah kesenian yang di tempat asalnya sudah tidak ditemukan lagi, namun justru masih tetap dilestarikan hingga saat ini di Barikin. Banyak orang yang datang ke desa ini untuk mempelajari seniseni tradisional, seperti musik dan tari, untuk kemudian dibawa ke daerahnya dan diajarkan di sana. Selain itu, banyak komunitas seni di Kalimantan Selatan merupakan hasil binaan dari para seniman dan seniwati dari Desa Barikin.

\section{b. Pelopor Musik Panting di Barikin}

Instrumen panting awalnya merupakan perangkat yang digunakan untuk hiburan pribadi, mengisi waktu luang saat sedang sendirian, dan belum disebut dengan "musik Panting". Lazimnya, seseorang mendendangkan pantun atau syair sambil memainkan instrumen panting saat naik perahu untuk mengisi kekosongan waktu agar tidak terasa sepi atau suntuk. Selain itu, seringkali orang juga memainkan instrumen panting sembari berdendang saat sedang menjaga tanaman di sawah atau kebun. Akhirnya, seiring perkembangan zaman, instrumen ini bersama-sama sejumlah instrumen lain disatukan dalam format sebuah ansambel musik, dan oleh penduduk lokal disebut dengan musik Panting.

Kemunculan musik Panting di Desa Barikin dipelopori oleh salah seorang tokoh seniman lokal, yakni A. W. Syarbaini. Berdasarkan silsilahnya, A. W. Syarbaini adalah pewaris komunitas Desa Barikin yang merupakan keturunan Datu Taruna. Darah seninya ia warisi dari para pendahulunya serta didukung oleh lingkungan sekitar, sehingga jiwa seni beliau yang sudah dimiliki sejak kecil semakin kuat. Andilnya cukup besar dalam usaha pelestarian dan pengembangan budaya dan seni tradisional di Kalimantan Selatan.

Menurut cerita masyarakat setempat, penduduk Desa Barikin berasal dari seorang ksatria kerajaan Negara Dipa (wilayah yang sekarang menjadi Hulu Sungai Utara) yang bergelar Datu Taruna. Bersama istri dan keluarganya, Datu Taruna membuka hutan dan mendirikan pemukiman di wilayah yang sekarang menjadi Desa Barikin. Selain merupakan seorang ksatria yang sangat disegani dan dihormati, Datu Taruna juga ahli dalam bidang kesenian keraton, khususnya gamelan Banjar (lihat Maman dkk., 2006: 10). Datu Taruna memiliki enam orang saudara, dua di antaranya memiliki keahlian di bidang seni keraton. Adik Datu Taruna yang nomor dua adalah seorang yang ahli dalam mendalang, sementara adik perempuannya yang bungsu, yang bergelar Datu Putih, ahli dalam seni tari keraton. Datu Taruna dan kedua adiknya inilah yang kemudian menyebarkan kesenian Keraton Banjar di Desa Barikin. Datu Taruna dan keluarganya, serta keturunannya kemudian menjadi sebuah komunitas besar dan membentuk suatu kelompok masyarakat, yakni masyarakat Desa Barikin.

A. W. Syarbaini lahir pada tanggal $8 \mathrm{Mei}$ 1955 di Desa Barikin, Kecamatan Haruyan, Kabupaten Hulu Sungai Tengah, Kalimantan Selatan. Sebagai putra ke empat dari sembilan bersaudara, ia terlahir dan dibesarkan di lingkungan keluarga seniman. Keterampilan seni diperolehnya secara otodidak dari orang tua dan para kerabat. Keterampilan seni yang pertama kali ia pelajari adalah gamelan Banjar dan tari klasik Banjar. Selain musik dan tari, A. W. Syarbaini juga belajar mendalang pada pamannya, Ki Dalang Tulur, seorang tokoh dalang di Kalimantan Selatan. Menginjak usia 14 tahun, A. W. Syarbaini telah memiliki cukup banyak pengalaman berkesenian 
dengan ikut serta dalam pementasan keliling kampung hingga pentas antarkota/kabupaten bersama orang tua, paman, serta masyarakat Desa Barikin lainnya. Mereka membawakan kesenian wayang kulit Banjar, wayang orang, wayang gong, dan kuda gepang dalam acaraacara hiburan masyarakat di masa itu. Dari pementasan-pementasan itulah ia banyak mendapat pelajaran berkesenian, selain juga ilmu yang diberikan secara langsung oleh orang tua dan pamannya.

Pada tahun 1973, A. W. Syarbaini membentuk sebuah sanggar seni tradisional di Desa Barikin. Sanggar itu ia beri nama "Ading Bastari". Pada waktu itu, Ading Bastari mengusung sejumlah seni pertunjukan rakyat, seperti wayang kulit Banjar, teater Melayu mamanda, tarian Melayu Banjar, tari kuda gepang, kesenian bajapin atau bagandut, wayang orang dan wayang gong. Sanggar Ading Bastari masih tetap eksis di Kalimantan Selatan hingga saat ini. Atas prestasi dan jasanya dalam usaha pelestarian dan pengembangan seni tradisional di Kalimantan Selatan, A. W. Syarbaini mendapat sejumlah penghargaan seni baik dari pemerintah provinsi maupun pemerintah pusat.

\section{c. Japin Gunung: Latar Belakang Musik Panting di Desa Barikin}

Menurut A. W. Syarbaini, kemunculan musik Panting di Desa Barikin dilatarbelakangi oleh kesenian japin gunung. Japin gunung merupakan sebuah bentuk seni pertunjukan berupa tari dan musik bernuansa Melayu yang sifatnya hiburan. Istilah japin merupakan perubahan pelafalan dari zapin, kesenian yang umum dijumpai di Alam Melayu. Zapin sendiri berasal dari kosakata Arab, zaffana, yang berarti langkah kaki atau gerakan kaki. Sebagai kesenian Melayu, zapin juga dijumpai dalam masyarakat Suku Banjar dan tersebar di berbagai wilayah Kalimantan Selatan dan mengalami perubahan penyebutan menjadi japin. Kesenian ini kemudian diadopsi oleh orang-orang bukit dan dibawa ke pedalaman, lalu berkembang menjadi japin gunung. Japin gunung yang berkembang di wilayah perbukitan atau pedalaman sudah berbeda dari japin yang berkembang di dalam masyarakat pesisir di Kalimantan Selatan, terutama dalam bentuk penyajiannya. Bentuk sajian japin dalam masyarakat pesisir bernuansa Islami dengan iringan musik Melayu Banjar. Musik pengiring tarian japin terdiri dari gambus Melayu, kaprak (marawis), babun (kendang), kampul (sejenis kempul), dan vokal. Lagu-lagu yang dibawakan dalam kesenian zapin adalah lagu zapin Melayu Banjar.

Di dalam masyarakat pedalaman, bentuk zapin mengalami sejumlah perubahan, baik dari segi tari, lagu, iringan, dan bentuk penyajian. Japin gunung menyajikan seni berbalas pantun sambil menari. Biasanya ada sepasang biduan, yakni satu pria dan satu wanita yang menari sembari menyanyi dan berbalas pantun. Bila salah satu di antara mereka tidak bisa membalas pantun yang dilontarkan oleh yang lainnya, maka yang tidak bisa membalas itu dianggap kalah dan akan mendapat ejekan dari penonton. Sebaliknya, bagi biduan yang pantunnya tidak dapat dijawab oleh pasangannya, dianggap menang dan akan mendapat uang sirih (sawer). Atau, bila ada salah satu penonton yang membuat salah seorang dari penonton merasa tersanjung atau tersentuh, maka orang tersebut biasanya juga akan memberikan uang sirih. Demikian seterusnya hingga pertunjukan selesai.

Instrumen yang digunakan untuk mengiringi japin gunung adalah panting, babun, dan kampul. Lagu yang dibawakan dalam pertunjukan japin gunung berbeda dengan lagu-lagu japin di wilayah pesisir. Lagu dalam japin gunung lebih kental dengan irama musik pedalaman, karena sudah dipengaruhi oleh budaya masyarakat lokal. Lagu yang dibawakan pun hanya satu, yang oleh masyarakat setempat biasa disebut dengan lagu japin gunung. Pertunjukan ini biasanya digelar pada malam hari untuk hiburan masyarakat.

Japin gunung hanya terdapat dalam masyarakat Desa Sungai Harang, Desa Batu 
Panggung, dan berkembang di masyarakat sekitar desa ini saja. Kapan dan siapa pencetus japin gunung di desa ini belum diketahui secara pasti, karena kesenian ini sudah lama punah di desa asalnya, dan tokoh-tokohnya pun sudah meninggal dunia. Kendati demikian, menurut masyarakat, terakhir japin gunung sering dipentaskan sebelum tahun 1970. Setelah tahun-tahun itu, kesenian ini tidak diketahui lagi keberadaannya di desa asalnya.

Tahun 1970, japin gunung dibawa dan dilestarikan di Desa Barikin oleh A. W. Syarbaini. Musik pengiring japin gunung, oleh A. W. Syarbaini juga digunakan untuk mengiringi tari-tari rakyat dan sering diundang oleh masyarakat sebagai hiburan untuk mengisi acara, misalnya dalam acara pernikahan dan peringatan hari-hari besar nasional, baik di desa-desa se-kecamatan atau antarkotakabupaten. Kesenian yang dibawakan pun berbeda-beda, misalnya teater atau tari rakyat Kalimantan Selatan, tergantung permintaan pihak yang mengundang.

Ketika akan memulai sebuah pertunjukan, baik tari ataupun teater rakyat, biasanya A. W. Syarbaini dan rekan-rekan pemusik memainkan musik iringan japin gunung sebagai pengisi waktu sekaligus untuk menarik dan mengumpulkan penonton. Setelah cukup banyak penonton yang datang, baru lah acara inti, yakni pertunjukan tari atau teater rakyat, disajikan. Musik iringan japin gunung yang disajikan di awal pertunjukan biasanya membawakan lagu-lagu rakyat Melayu Banjar yang sudah ada. Selain itu, tidak ketinggalan pula dimainkan lagu japin gunung itu sendiri.

Sajian musik iringan japin gunung pertama kali dipentaskan tahun 1970-an, menggunakan instrumen yang sama dengan kesenian aslinya. Namun, yang disajikan di sini hanya berupa musik dan lagu saja; vokalis hanya menyanyi, tidak sambil menari. Dalam pertunjukan ini, para pemain biasanya mengambil posisi berdiri atau duduk di kursi. Lazimnya, yang berada di posisi paling depan adalah vokalis dan pemain gambus, selanjutnya di belakangnya adalah pemain babun (gendang) yang sejajar dengan pemain kampul dan giring-giring. Atau, pemain giringgiring dan kampul juga bisa ditempatkan di belakang pemain babun. Kendati demikian, susunan tersebut bukanlah susunan yang baku atau mutlak; susunan bisa berubah sesuai dengan kebutuhan para pemain.

A. W. Syarbaini biasanya mengambil peran sebagai pemain panting dalam pertunjukan dan sesekali juga memainkan biola. Lagu-lagu yang dibawakan dalam pertunjukan ini masih sangat terbatas dan cara penyajiannya pun terbilang masih sangat sederhana atau belum mengenal variasi dan aransmen lagu. Pada masa itu, pertunjukan ini juga belum memiliki penamaan atau penyebutan yang baku. Namun, karena pertunjukan ini menyajikan musik dan lagu saja, masyarakat sering menyebutnya dengan istilah acara banyanyanyian (bernyanyinyanyi) atau musik japin. Acara banyanyanyian pada waktu itu hanyalah hiburan untuk mengumpulkan penonton dalam sebuah acara pertunjukan. Artinya, banyanyanyian tidak pernah digelar secara mandiri, melainkan hanya untuk mengawali sebuah pementasan seni pertunjukan saja.

Banyanyanyian waktu itu mulai digemari oleh masyarakat di sekitar Desa Barikin. Oleh karena itu, muncullah keinginan hati A. W. Syarbaini untuk lebih mengembangkannya agar semakin dikenal di masyarakat luas, khususnya di daerah Kalimantan Selatan. Langkah awal yang dilakukannya ialah menggali lagu-lagu rakyat, khususnya yang ada di Desa Barikin, dan lagu-lagu Melayu Banjar pada umumnya. Ini dilakukan untuk menambah perbendaharaan lagu dalam acara banyanyanyian. Satu demi satu lagu rakyat dan lagu Melayu Banjar ia pelajari dan ia kumpulkan dari masyarakat Desa Barikin secara lisan.

Masyarakat Desa Barikin yang seluruhnya beragama Islam memiliki kebiasaan berzikir sambil berpantun dengan lagu-lagu bernuansa Melayu. Zikir ini biasa disebut masyarakat 
setempat dengan istilah zikir simak, karena dalam zikir ini diselingi pantun dengan syair bermakna ketuhanan yang harus disimak dan dipahami dengan sungguh-sungguh. Zikir simak, dalam lagu-lagunya, biasanya diiringi dengan satu buah alat musik sejenis siter yang biasa disebut masyarakat setempat dengan panting mandolin dan tarbang buldarah (terbang atau gendang Melayu berukuran besar) sebanyak empat buah sehingga masyarakat biasa menyebutnya dengan tarbang ampat (terbang empat).

Selain untuk mengiringi zikir simak, tarbang ampat dalam masyarakat Barikin juga digunakan sebagai iringan dalam Maulid Rasul Al Barzanji yang biasa disebut masyarakat dengan maulid tarbang ampat. Zikir simak dan maulid tarbang ampat dibawa oleh Auliya Syekh Abdussyukur Shihab, seorang ulama yang masih berdarah Barikin, yang menurut riwayat menuntut ilmu agama di Mekah dan merupakan seorang pelopor agama Islam di Desa Barikin. Kendati demikian, asal-usul seni tarbang ampat ini belum diketahui secara pasti, karena belum ditemukan data yang akurat terkait hal tersebut. Pada dasarnya, instrumen dan ansambel terbang umum dijumpai dalam masyarakat yang mayoritas memeluk agama Islam. Konon, terbang diperkenalkan oleh pedagang dari Arab dan Afrika Utara (Irawan, 2010: 97).

Auliya Syekh Abdussyukur Shihab adalah seorang ulama yang menggunakan seni musik sebagai media dakwahnya terutama di Desa Barikin. Musik yang digunakan adalah zikir simak. Ketika membawakan zikir simak, ia biasanya memainkan panting mandolin sambil melantunkan lagu-lagunya. Menurut cerita masyarakat setempat, ke manapun ia pergi, selalu membawa panting mandolin dan selalu ia mainkan saat sedang sendiri sembari mendendangkan pantun-pantun yang bermakna sufi. Banyak lagu, pantun, dan syair ciptaannya untuk zikir simak dan lagu untuk menyanyikan syair-syair Barzanji yang masih digunakan oleh masyarakat setempat sampai saat ini.
Dahulu banyak di antara masyarakat Desa Barikin yang merantau ke daerah di Pulau Sumatera, yaitu daerah Tembilahan (Kepulauan Riau) dan Batu Pahat (Malaysia), termasuk Auliya Syekh Abdussyukur. Menurut informasi masyarakat setempat, banyak juga lagu Melayu yang dibawa dari dua daerah ini, seperti lagu-lagu senandung dan zapin Melayu, untuk digunakan sebagai lagu zikir simak dan maulid tarbang ampat. Tidak menutup kemungkinan seni buldarah atau tarbang ampat diadopsi dari Malaysia, sebab menurut catatan sejarah, masuknya instrumen terbang (gendang Melayu) berasal dari daerah Malaka, Malaysia (Sanderta dkk., 2000: 22).

Dari zikir simak dan maulid tarbang ampat inilah A. W. Syarbaini banyak memperoleh lagu untuk digunakan dalam acara banyanyanyian. Dalam banyanyanyian, syair yang dibawakan bukanlah syair dari zikir simak atau Barzanji, melainkan diganti dengan pantun-pantun bebas atau tidak baku untuk lagu tersebut. Artinya, pantun dalam lagu-lagu banyanyanyian bisa berubah sesuai dengan keinginan sang vokalis, karena pada saat itu A. W. Syarbaini belum mengenal istilah mencipta lagu. Oleh karena itu, lagulagu yang dibawakan dalam banyanyanyian hanya berkutat di seputar lagu rakyat dan lagu Melayu Banjar yang sudah ada, khususnya lagu-lagu peninggalan Auliya Syekh Abdussyukur yang tergolong masih kakek buyutnya.

Acara banyanyanyian terus dipentaskan untuk mengawali sebuah pertunjukan yang akan ditampilkan oleh A. W. Syarbaini setiap kali ada undangan masyarakat untuk mengisi acara hiburan. Tentu saja, lagu-lagu yang disajikan pun sudah mulai bertambah. Banyanyanyian atau musik japin makin dikenal oleh masyarakat Hulu Sungai Tengah pada masa itu, terutama masyarakat pedesaan.

Keinginan A. W. Syarbaini untuk terus menggali seni tradisi di Kalimantan Selatan tidak hanya sampai di situ. Ia terus mencari dan mengumpulkan informasi di masyarakat tentang seni dan budaya daerah Kalimantan 
Selatan. Informasi tentang kesenian banyak ia peroleh dari masyarakat ketika mendapat undangan untuk menggelar pertunjukan di desa-desa yang tersebar di berbagai penjuru Kalimantan Selatan. Dari sini pula lah ia berkenalan dengan tokoh-tokoh seni tradisi Kalimantan Selatan. Kesempatan ini tidak ia sia-siakan begitu saja; ia banyak menggali dan belajar, khususnya di bidang seni dan budaya dari tokoh-tokoh yang ia temui.

Di Desa Pandahan, Kabupaten Tapin, yang masyarakatnya masih termasuk suku Banjar Hulu, ada sebuah seni pertunjukan yang disebut bagandut, atau yang lebih dikenal luas dengan sebutan kesenian bajapin. Bagandut atau bajapin adalah kesenian yang sejenis dengan ronggeng atau tayuban yang ada di Pulau Jawa. Gandut adalah sebutan untuk penari atau biduan dalam kesenian ini. Kendati demikian, arti gandut dalam kesenian ini tidak diketahui secara pasti. Masyarakat setempat juga tidak mengetahui apa arti gandut yang sebenarnya. Penyebutan ini sudah ada sejak zaman kakek-nenek mereka. Dalam kamus bahasa Banjar, kata gandut berarti gendut atau buncit. Namun, kata gandut yang digunakan dalam penyebutan bagandut belum diketahui artinya. Perlu studi lebih lanjut untuk memperoleh data yang akurat. Menurut masyarakat lokal, kesenian bagandut sudah ada sejak zaman nenek moyang dan diwariskan secara turun-temurun secara lisan di kalangan masyarakat Desa Pandahan. Kapan persisnya kesenian ini muncul, dan siapa pencetusnya, belum diketahui.

Kesenian bagandut menyajikan lagulagu rakyat setempat dan mengajak penonton untuk menari bersama gandut yang ada dengan cara memberikan uang sirih (sawer) kepada gandut tersebut. Bagandut biasanya dipentaskan pada malam hari sebagai hiburan untuk masyarakat seusai panen raya atau pada perayaan-perayaan lainnya, khususnya di Desa Pandahan. Lagu-lagu dalam kesenian bagandut masih bernuansa Melayu Banjar dengan iringan instrumen musik yang nyaris sama dengan iringan japin gunung, yaitu satu buah panting, satu buah babun, giring-giring, satu buah kampul, satu buah rabab (sejenis rebab, terbuat dari batok kelapa dan kulit ular), serta gandut (vokalis sekaligus penari).

Bagandut memiliki beberapa kesamaan dengan japin gunung. Perbedaan antara keduanya hanya terletak pada instrumen dan bentuk penyajian. Instrumen rabab yang digunakan dalam bagandut tidak dijumpai dalam japin gunung; dalam japin gunung, penonton tidak diajak untuk ikut menari, sementara dalam bagandut penonton diajak berpartisipasi menari bersama sang gandut. Kendati demikian, kedua kesenian tersebut memiliki latar belakang yang sama, yakni dari kesenian ronggeng Melayu.

Bagandut atau bajapin tidak luput dari perhatian A. W. Syarbaini. Ia mendatangi beberapa tokoh kesenian ini di Desa Pandahan yang masih memiliki hubungan keluarga dengannya untuk belajar secara langsung. Setelah beberapa lama mendalami bagandut, terutama dalam hal lagu-lagunya, kesenian ini ia bawa ke Desa Barikin. Di sana, ia membentuk kesenian bagandut pada tahun 1973. Karena di Barikin sudah dikenal japin gunung, maka kesenian bagandut ini tidak begitu asing dan dapat diterima dengan baik oleh masyarakat setempat. Bahkan, masyarakat sangat menggemari kesenian bagandut yang dibawa oleh A. W. Syarbaini dari Desa Pandahan ini. Saat itu, di Barikin belum ada yang mampu menjadi seorang gandut, sebab bagandut memiliki lagu dan tarian yang khas dan beragam. Jika ada permintaan dari masyarakat, biasanya ia menjemput gandut dari Pandahan untuk membantu pertunjukannya.

Bagandut, yang oleh masyarakat Barikin sering disebut bajapin, sangat populer di Hulu Sungai Tengah dan Selatan. Dalam perkembangannya, keberadaan kesenian ini menggeser popularitas japin gunung yang sudah lebih dahulu dikenal oleh masyarakat Barikin dan sekitarnya. Setelah masuknya bagandut di Desa Barikin, japin gunung menjadi sangat jarang digelar di kalangan 
masyarakat. Ini antara lain disebabkan karena tidak ada lagi generasi penerus di desa asalnya, selain juga masyarakat lebih tertarik dengan bajapin. Sejak itu pula lah japin gunung lambat laun jarang muncul hingga akhirnya tidak pernah digelar atau bisa dikatakan punah.

Kesenian bagandut juga memberi pengaruh pada musik japin atau acara banyanyanyian, terutama pada lagu-lagu dari kedua kesenian ini. Lagu-lagu bagandut sering dibawakan dalam musik japin atau banyanyanyian di samping lagu-lagu yang terdahulu. Alhasil, pertunjukan ini semakin berkembang dan digandrungi oleh masyarakat. Meskipun perkembangan terjadi hanya dalam hal jumlah lagu yang dibawakan dan belum ada sentuhan lain yang lebih jauh, namun harus diakui bahwa ini cukup disukai oleh masyarakat.

Jika A. W. Syarbaini sudah memetik dawai-dawai panting-nya dan melantunkan lagu-lagu Melayu Banjar dengan diiringi instrumen lain, sebagian masyarakat sudah tahu bahwa yang akan mengadakan pertunjukan adalah kelompok atau rombongan A. W. Syarbaini. Mereka lalu berkumpul di lokasi pertunjukan untuk menikmati banyanyanyian atau musik japin dan pertunjukan inti yang akan digelar setelah itu. Ini disebabkan karena banyanyanyian atau musik japin yang mendahului sebuah pertunjukan hanya disajikan oleh kelompok A. W. Syarbaini dari Desa Barikin. Pada tanggal 15 November 1977, musik japin ditampilkan secara khusus dalam resepsi perkawinan A. W. Syarbaini di Desa Barikin. Dalam acara ini, musik japin disajikan sebagai musik pengantar, serta untuk menyambut sekaligus menghibur para tamu yang hadir. Instrumen yang digunakan dan lagu yang dibawakan dalam musik japin masih belum mengalami perkembangan, hanya saja pertunjukan ini dikhususkan untuk sajian musik japin.

Pada resepsi tersebut, hadir pula sejumlah tokoh seniman di Kalimantan Selatan, antara lain Yustan Azidin (almarhum), Marsudi B.
A., Anang Ardiansyah, dan Drs. Bakhtiar Sanderta. Para tokoh seni ini tertarik melihat pertunjukan musik japin yang ditampilkan, dan mereka turut bernyanyi secara bergantian. Dari sinilah kemudian pertunjukan musik japin mulai mendapat perhatian di tingkat provinsi, khususnya dari para senimannya.

Pada tahun 1979 pertunjukan musik japin mengalami perkembangan, khususnya dalam hal instrumen dan lagu yang dibawakan. Instrumen yang digunakan saat itu mengalami penambahan jumlah dan jenis: panting, yang tadinya hanya satu, menjadi tiga buah; lima buah kulimpat (sejenis ketipung); suling; agung basar (sejenis gong suwuk); babun (gendang) dan giring-giring tidak mengalami perubahan. Sejak tahun ini pula A. W. Syarbaini mulai menciptakan lagu-lagu tradisional khusus untuk pertunjukan musik japin (A. W. Syarbaini, Komunikasi Pribadi, 6 Maret 2007).

Pada tahun 1985, kesenian ini diikutkan dalam festival musik rakyat tingkat nasional di Jakarta, yang diwakili oleh kontingen dari Kabupaten Tapin Rantau, dan masuk dalam kategori 10 penyaji terbaik. Saat akan diberangkatkan, kesenian ini masih belum memiliki nama definitif atau resmi. Akhirnya, dari hasil kesepakatan beberapa tokoh seni, di antaranya Bakhtiar Sanderta, Yustan Azidin, dan Anang Ardiansyah, kesenian ini diberi nama musik Panting. Alasan utamanya adalah karena instrumen panting merupakan instrumen utama, yakni pembawa lagu dalam kesenian ini. Sejak saat itu kesenian tersebut mulai berkembang, dikenal dengan nama musik Panting, dan diakui masyarakat sebagai kesenian rakyat Kalimantan Selatan.

Pertunjukan musik Panting pada awalnya hanya dijumpai di Desa Barikin. Namun, kesenian ini kemudian menyebar luas di kalangan masyarakat Kalimantan Selatan. A. W. Syarbaini dan musik Panting-nya kerap diundang di tingkat provinsi untuk tampil dalam berbagai acara. Selain itu, masyarakat juga menyukai kesenian ini dan sering menggelarnya dalam acara perkawinan. 
Sejak itulah musik Panting memasyarakat di Kalimantan Selatan, yang antara lain ditandai dengan munculnya grup-grup musik panting di daerah lain. Tidak hanya di kalangan masyarakat awam, musik Panting juga disebarluaskan di sekolah-sekolah dengan cara membagikan alat-alat musik Panting yang dilakukan oleh Pemerintah Daerah Kalimantan Selatan.

\section{Keberadaan Musik Panting}

Kebudayaan bersifat dinamis, berubah seiring dengan perubahan yang dialami oleh masyarakat pemiliknya. Demikian pula yang terjadi dalam kabudayaan masyarakat Banjar, tidak terkecuali yang hidup di Desa Barikin. Masyarakat Barikin masih memelihara adat istiadat dan budaya warisan leluhur mereka. Namun, mereka tidak serta merta menutup diri dari perubahan zaman dan menerima pengaruh akibat kontak yang terjadi dengan kelompok masyarakat lain. Perubahan ini antara lain terlihat dari cara berpakaian, terutama anak muda yang selalu mengikuti perkembangan mode, kepemilikan alat elektronik seperti televisi, alat komunikasi, alat transportasi, dan sebagainya. Perubahan zaman, tidak dapat dipungkiri, juga berdampak pada keberadaan musik Panting.

\section{a. Musik Panting Tahun 1985}

Sejak tahun 1970-an, A. W. Syarbaini sering diutus sebagai delegasi oleh pemerintah daerah untuk menjadi wakil dalam festivalfestival kesenian tradisional, baik musik, tari, atau acara lainnya di tingkat nasional. Dari sinilah ia banyak melihat perkembangan kesenian-kesenian di daerah lain di Indonesia, dan menjadikannya sebagai referensi dan perbandingan untuk pengembangan kesenian yang ada di Desa Barikin secara khusus, dan Kalimantan Selatan secara umum. Pengalaman kesenian di luar daerah ini memberikan pengaruh, secara langsung ataupun tidak, terhadap perkembangan kesenian yang ada di Desa Barikin.

Tahun 1985 merupakan era perkembangan musik Panting, khususnya di Desa Barikin, dan kemudian menyebar di kalangan masyarakat Kalimantan Selatan pada umumnya. Pada tahun 1985, A. W. Syarbaini mulai menggunakan perangkat elektronik untuk menunjang pertunjukan musik Panting-nya, meskipun terbilang masih sangat sederhana. Perangkat elektronik yang digunakan adalah beberapa buah alat pengeras suara, agar kualitas suara yang dihasilkan lebih maksimal. Beberapa buah perangkat pengeras suara yang digunakan dalam pertunjukan musik Panting pada awalnya adalah beberapa buah mikrofon, satu unit amplifier dan satu unit speaker corong. Menurut A. W. Syarbaini, sebagian dari perangkat tersebut biasanya disewa dari tetangga, dan sebagian merupakan milik sendiri. Dengan alat yang terbilang masih sederhana ini, A. W. Syarbaini bersama rombongan musik Panting-nya mengadakan pertunjukan untuk memenuhi keinginan atau permintaan masyarakat, baik di daerah Hulu Sungai Tengah sendiri maupun ke luar wilayah kabupaten ini.

Pendapatan yang diperoleh dari pementasan, juga sebagian sisa honorarium para pemain ditabung atau dimasukkan ke dalam kas kelompok untuk biaya peralatan dan penambahan alat-alat yang masih kurang. Uang kas yang terkumpul, ditambah dengan dana pribadi A. W. Syarbaini, digunakan untuk membeli sedikit demi sedikit perangkat sound system serta memperbarui sebagian alat musik panting yang dinilai sudah kurang layak pakai. Sebagian dari perangkat sound system dibeli dalam bentuk sudah jadi, sementara sebagian lainnya dirakit atau dirangkai sendiri dengan membeli bahan-bahannya terlebih dahulu. Ini dilakukan karena dana yang dimiliki tidak cukup untuk membeli perangkat sound system yang sudah jadi secara lengkap. Pada tahun ini pula A. W. Syarbaini mulai banyak menciptakan lagu untuk pertunjukan musik Panting. Salah satu lagu ciptaannya yang cukup dikenal hingga saat ini adalah lagu berjudul "Musik Panting” dan "Ayun Apan”. Instrumen panting juga mulai mengalami perubahan dalam hal konstruksinya pada tahun 1985. A. W. Syarbaini berinisiatif mengganti kulit penutup 
kotak resonator dengan menggunakan kayu tipis. Hal ini ia lakukan karena berdasarkan pengalaman, kulit penutup resonator instrumen panting jika digunakan pada malam hari atau terkena udara dingin akan menjadi lembab dan kendur, sehingga suara yang dihasilkan tidak maksimal. Hal seperti ini tidak lagi terjadi setelah penutup resonator diganti dengan kayu tipis.

Pada era 1980-an, di kalangan masyarakat pedesaan, terutama di daerah Hulu Sungai Tengah, sudah populer musik dangdut. Di Desa Barikin, musik dangdut juga sering dipentaskan oleh masyarakat setempat. Grup musik dangdut biasanya datang dari Kota Banjarmasin dan mengadakan pertunjukan keliling ke daerah-daerah kabupaten sampai ke pelosok pedesaan. Musik dangdut ini biasa dipentaskan pada malam hari. Dalam pertunjukannya, mereka menggunakan perangkat sound system yang lengkap sehingga suasana yang tercipta terkesan sangat meriah. Dangdut cukup digandrungi oleh masyarakat, sehingga hampir setiap ada perayaan, musik dangdut nyaris selalu disertakan sebagai hiburan pada malam harinya.

A. W. Syarbaini sering menyaksikan pertunjukan musik dangdut di Desa Barikin. Ia kemudian tertarik dengan perangkat sound system yang digunakan dalam pertunjukan musik tersebut. Dari sini lah kemudian muncul pemikirannya untuk mencoba menggunakan perangkat sound system serupa dalam pertunjukan musik Panting. Oleh karena itu, ia kemudian belajar cara menggabungkan sebuah alat musik ke dalam perangkat sound system.

\section{b. Musik Panting Tahun 1989}

A. W. Syarbaini mengumpulkan perangkat sound system dengan menggunakan pendapatan atau hasil pementasan musik Panting yang ditambah dengan dana milik pribadi. Satu demi satu perangkat sound system mulai terkumpul dan alat-alat dalam ansambel musik Panting juga diperbarui. Menurutnya, usaha ini dilakukan selama bertahun-tahun. Pada tahun 1989, A. W.
Syarbaini sudah menggunakan sound system layaknya pertunjukan musik dangdut, antara lain beberapa unit sound control, sound untuk di luar panggung, mixer, mesin power, dan alat elektronik lainnya.

Sejak tahun 1989 ini juga mulai banyak diciptakan lagu untuk musik Panting. Selain ciptaan A. W. Syarbaini, banyak juga lagu yang diciptakan oleh salah seorang anggota rombongannya, yaitu M. Aini. Sejak usia 13 tahun (tahun 1970), M. Aini sudah bergabung dengan, atau mengikuti A. W. Syarbaini, sebagai pemain panting dalam kesenian bajapin. Ia menciptakan lagu untuk musik Panting sejak tahun 1989 hingga sekarang. Lagu-lagu ciptaan A. W Syarbaini dan M. Aini masih dibawakan hingga saat ini oleh grupgrup musik Panting lainnya di Kalimantan Selatan.

\section{c. Musik Panting Tahun 1990}

Sejak tahun 1990, penggunaan perangkat sound system dalam pertunjukan musik Panting diikuti oleh grup-grup musik Panting lainnya di berbagai wilayah Kalimantan Selatan. Pada masa ini pula, menurut keterangan A. W. Syarbaini, ia mendapat proyek dari Kanwil Depdikbud Provinsi Kalimantan Selatan untuk membuat instrumen panting dalam jumlah banyak guna dibagikan ke sekolahsekolah. Ini merupakan salah satu upaya pemerintah daerah setempat dalam rangka pengembangan musik Panting di Kalimantan Selatan.

Instrumen musik merupakan salah satu hasil budi daya manusia yang juga memiliki ciri atau sifat kebudayaan, yaitu tidak lepas dari perubahan. Faktor yang antara lain mempengaruhi perubahan instrumen musik adalah lingkungan (masyarakat) dan akulturasi Kebudayaan (Banoe, 1984: 11). Hal ini juga terjadi pada instrumen panting. Pada awal tahun 1990, A. W. Syarbaini melakukan eksplorasi dan eksperimen terhadap instrumen panting. Ia mencoba membuat panting elektrik dengan cara memasang perangkat pengeras suara (spool) pada instrumen tersebut. Sebelumnya, ia hanya menggunakan 
mikrofon eksternal yang terhubung dengan mixer dan loudspeaker untuk mengamplifikasi bunyi instrumen panting. Menurutnya, cara ini kurang begitu praktis dan suara yang dihasilkan belum benar-benar maskimal. Oleh karena itu, timbul keinginannya untuk membuat amplifikasi panting yang lebih praktis tanpa harus mengubah bentuk instrumen tersebut.

Panting elektrik dengan hasil yang maksimal akhirnya berhasil dibuat oleh A. W. Syarbaini setelah melewati beberapa kali uji coba. Setelah itu, ia mulai berpikir tentang aransmen musik Panting. Saat itu, dalam pertunjukan, ia menggunakan tiga buah instrumen panting, namun ketiganya memiliki fungsi yang sama dalam permainannya, yakni sebagai pembawa melodi pokok lagu. Ia kemudian mencoba membagi fungsi musikal dalam permainan instrumen panting.

Tiga buah panting masing-masing ia beri fungsi yang berbeda. Panting satu tetap sebagai pembawa melodi pokok lagu, panting dua berfungsi sebagai pemberi variasi satu, dan panting tiga berfungsi memberikan variasi dua karena masing-masing instrumen panting kini sudah memiliki fungsi berbeda, maka penamaannya pun dibedakan sesuai fungsinya itu: panting satu, karena berfungsi sebagai pembawa melodi pokok, disebut dengan panting pambawa; panting dua dinamai panting paningkah; dan panting tiga diberi nama panting panggulung.

Pemanfaatan teknologi dalam pertunjukan musik sedikit-banyak turut berpengaruh terhadap penerimaan masyarakat terhadap musik itu. Pertunjukan musik Panting dengan menggunakan sound system lebih disukai masyarakat, sebab bunyi setiap instrumen dapat terdengar lebih maksimal, jangkauannya lebih jauh sehingga lebih banyak orang yang mendengarkan dan hadir, dan kesan yang dimunculkan lebih meriah. Kendati demikian, tidak semua orang berpandangan demikian. Ada beberapa tokoh seni yang awalnya menyatakan ketidak-setujuannya dengan penggunaan perangkat sound system dalam pertunjukan musik Panting. Alasannya antara lain ialah bahwa kehadiran perangkat ini dikhawatirkan merusak citra seni tradisi, dalam hal ini musik Panting. Namun, tentu A. W. Syarbaini memiliki alasan tersendiri di balik penggunaan perangkat modern pada saat itu, yakni agar musik Panting bisa bersaing dengan musik dangdut yang kala itu sangat populer di masyarakat. Ia berharap agar musik Panting dapat lebih diminati dan berkembang di kalangan masyarakat yang lebih luas.

Musik Panting di daerah Barikin kemudian menyebar ke daerah-daerah lain di Kalimantan Selatan. Hampir di setiap daerah terdapat grup musik Panting, dan sebagian di antaranya merupakan hasil binaan A. W. Syarbaini. Grup binaannya tidak hanya berasal dari Hulu Sungai Tengah saja, melainkan juga dari Hulu Sungai Selatan, Tabalong, hingga Banjarmasin. Bahkan, boleh dikatakan bahwa musik Panting di Desa Barikin merupakan kiblat musik Panting di Kalimantan Selatan. Setiap perkembangan yang terjadi di Barikin selalu dicontoh oleh grup-grup lain di Kalimantan Selatan.

Perbedaan pendapat antara beberapa tokoh seni di Kalimantan Selatan soal penggunaan perangkat sound system dalam pertunjukan musik Panting lambat laun dapat diselaraskan. Mereka yang tadinya kontra menjadi dapat menerima setelah mendapati bahwa pertunjukan musik Panting yang memanfaatkan teknologi sound system sangat digandrungi dan berkembang luas di masyarakat.

Pengembangan musik Panting di Desa Barikin tidak hanya berkutat pada penggunaan perangkat amplifikasi saja. A. W. Syarbaini juga melakukan aktivitas kreatif lain terkait musik Panting. Hal ini dilakukan agar musik ini bisa tetap tumbuh dan berkembang di masyarakat. Musik Panting sudah diakui sebagai musik tradisi asli Kalimantan Selatan, sehingga harus tetap dijaga keberadaannya. Tanpa ada dukungan dari masyarakat, maka dapat hampir dipastikan keberadaan kesenian tersebut akan terancam. 


\section{d. Musik Panting Tahun 1995, Era Tahun 2000-an, hingga Sekarang}

Untuk menjaga kelestarian musik Panting di Kalimantan Selatan, khususnya di Desa Barikin, A. W. Syarbaini berinisiatif membina anak-anak untuk mempelajari musik ini. Pada tahun 1995, ia membina anakanak setempat yang berusia antara 6-10 tahun untuk memainkan musik Panting. Kelompok anak-anak ini ia namai "Musik Panting Cilik", karena memang semua pemainnya terdiri dari anak-anak. Diharapkan anak-anak ini nanti akan menjadi generasi pelaku musik Panting.

Format Musik Panting Cilik ini tidak seperti yang lazimnya dibawakan oleh orang dewasa. Instrumen musik yang digunakan lebih sedikit, yakni dua buah panting berukuran kecil, satu buah babun, agung basar, kampul, giring-giring, dan kulimpat, serta dua orang vokalis atau lebih. Musik Panting Cilik juga sering ditampilkan dengan format kolaborasi dengan gamelan Banjar, namun hanya dalam peristiwa tertentu saja.

Musik Panting Cilik ini cukup menyita perhatian Pemerintah Daerah Kalimantan Selatan. Oleh karena itu, kelompok ini sering diundang ke tingkat provinsi untuk mengisi acara tertentu. Ini antara lain dilakukan agar Musik Panting Cilik dapat lebih dikenal dan memasyarakat, terutama di daerah Kalimantan Selatan. Ini juga merupakan salah satu cara untuk menarik minat anak-anak untuk mau mempelajari dan lebih mengenal seni tradisi, sehingga pada gilirannya musik Panting khususnya, dan juga seni tradisi lainnya, dapat diwariskan terus dari generasi ke generasi.

Perhatian pemerintah daerah terhadap Musik Panting Cilik tidak hanya sampai di situ. Beberapa upaya lain juga dilakukan untuk mengenalkan dan melestarikannya. Pada tahun 1999, kelompok Musik Panting Cilik dari Barikin ini diutus untuk mengiringi teater anak dalam rangka Festival Teater Anak Nusantara Tingkat Nasional di Jakarta, dan berhasil meraih predikat musik terbaik. Tahun 2000, mereka kembali menjadi delegasi Kalimantan Selatan dalam Festival Musik
Tradisi Anak Nusantara Tingkat Nasional di Jakarta, dan masuk dalam kategori 5 besar.

Musik Panting di Desa Barikin masih terus berkembang hingga kini. Hingga akhir hayatnya, A. W Syarbaini (1955-2016) terus membina musik Panting baik di Barikin maupun di daerah lain dalam wilayah Kalimantan Selatan. Lagu-lagu musik Panting yang sudah ada atau ciptaan baru biasanya diaransemen dengan menggunakan irama musik lain, misalnya irama dangdut jaipong dan irama musik tingkilan. Menurut Irawati (2013: 2) Tingkilan merupakan salah satu jenis kesenian musik masyarakat Kutai yang berasal dari perjalanan masuknya Islam ke Kutai dan memiliki kesamaan dengan kesenian rumpun Melayu yang kemudian beralkulturasi dengan budaya-budaya lain yang ada di Kutai seperti idiom musik keroncong jenis langgam, hadrah, melayu dan lain-lain. Tetapi yang tetap membuat musik tersebut masih dikatakan Tingkilan adalah dari instrumen gambus yang dipakai, irama musik dan syair lagu yang digunakan.

Grup musik Panting Pandan Sari dari Desa Tabat Padang, Kecamatan Haruyan, Kabupaten Hulu Sungai Tengah, merupakan salah satu hasil binaan A. W Syarbaini. Menurut Romeo, mereka membangun kelompok ini sejak tahun 2002 dan belajar di Sanggar Ading Bastari, Desa Barikin. Kelompok lain yang merupakan binaan beliau adalah Grup Moneca dari Desa Masimpan, Kecamatan Telaga Langsat, Kabupaten Hulu Sungai Selatan. Menurut Iyus, kelompok tersebut dibentuk tahun 2003, dan mereka juga belajar dari Sanggar Ading Bastari.

A. W. Syarbaini juga sering menyajikan pertunjukan musik Panting dengan sajian berbeda untuk menarik minat masyarakat, misalnya mengkolaborasikannya dengan instrumen musik lain. Ia beberapa kali mengkolaborasikan musik Panting dengan gamelan Banjar maupun musik band, namun hanya dalam kesempatan tertentu saja. Kendati demikian, dalam pertunjukan biasa seperti dalam acara perkawinan, musik 
Panting tetap disajikan dalam format tradisi. Perkembangan lain dari musik Panting di Kalimantan Selatan adalah adanya beberapa grup musik Panting yang mengkolaborasikan musiknya dengan musik dangdut atau panting dangdut. Grup semacam ini juga disukai dan sering ditampilkan di tengah masyarakat, meski ada juga kelompok masyarakat yang tidak setuju dengan panting dangdut semacam ini karena dianggap mengurangi nilai tradisinya.

Menurut pandangan A. W. Syarbaini, kolaborasi panting dangdut adalah hal yang wajar, karena ia menganggapnya sebagai salah satu bukti bahwa musik Panting sudah berkembang di masyarakat. Kendati demikian, ia tetap bertahan dengan musik Panting dalam bentuk sajian tradisi, agar generasi berikutnya masih dapat mengetahui bentuk asli dari musik Panting. Pendapat ini selaras dengan beberapa tokoh seni di Kalimantan Selatan yang mengemukakan bahwa seni tradisi boleh berkembang, namun bentuk aslinya jangan sampai hilang.

Untuk memelihara keberlangsungan musik Panting di Kalimantan Selatan, setiap tahunnya diadakan lomba musik Panting di tingkat provinsi, baik antarpelajar, guruguru sekolah, dan antargrup musik Panting. Ini antara lain bertujuan agar musik Panting dapat juga berkembang di lembaga-lembaga pendidikan selain di masyarakat umum. Dengan demikian, keberlangsungan musik ini bisa tetap terpelihara dan diteruskan dari generasi ke generasi. Inilah yang antara lain menyebabkan hampir setiap sekolah di Kalimantan Selatan memiliki kelompok musik Panting dan musik ini menjadi salah satu pelajaran muatan lokal.

\section{Musik Panting sebagai Hasil Laku Kreatif}

Desa Barikin, sebagai basis seni di Kalimantan Selatan, merupakan sebuah ruang yang sangat potensial bagi kehidupan seni itu. Mengapa demikian? Pertama, orang-orang yang tinggal atau hidup di desa ini, mau tidak mau, sengaja atau tidak, pasti banyak bersinggungan dengan aktivitas seni, baik itu secara pasif (menjadi pendengar, penonton, penikmat) maupun secara aktif (menjadi pemusik, penari, penampil, dan semacamnya). Hal ini antara lain disebabkan karena banyak aktivitas seni yang terjadi di tempat ini. Kedua, dan pada dasarnya merupakan rangkaian dari alasan pertama, ada orang (atau mungkin banyak orang) di desa ini yang memiliki kemampuan dan dedikasi di bidang seni, yang kemudian membuat iklim berkesenian di Barikin menjadi aktif. Desa Barikin memiliki potensi seni, sehingga masyarakat jadi terlatih dan terpacu untuk berkesenian; sebaliknya, ada (atau banyak) orang di Desa Barikin yang mumpuni dalam bidang seni, sehingga kesenian di desa ini menjadi hidup dan berkembang. Tentu saja, kedua logika ini saling terkait membentuk suatu lingkaran yang sulit untuk ditentukan ujung pangkalnya. Kendati demikian, ini dapat dipahami sebagai bentuk aksi dan reaksi (gambar 1).

Salah satu tokoh seni yang ada di Barikin adalah A. W. Syarbaini. Berdasarkan kerangka pikir di atas, maka bisa diasumsikan bahwa kondisi atau kehidupan seni di Barikin turut membentuk A. W. Syarbaini sebagai seseorang yang memiliki pengetahuan dan keterampilan mumpuni di bidang seni, sementara di sisi lain keberadaan A. W. Syarbaini ini juga memberikan dorongan bagi geliat seni di Desa Barikin. Dengan kemampuan dan kepekaannya, A. W. Syarbaini mencoba merespon keadaan di Barikin, melihat adanya ruang-ruang yang memungkinkan munculnya bentuk-bentuk aktivitas baru. Bisa jadi beliau sendiri tidak berpikir tentang memunculkan sesuatu yang baru, melainkan hanya merespon saja apa yang ada. Namun, bisa juga ia memang sudah memikirkan akan munculnya sebuah bentuk baru.

Keberadaan japin gunung agaknya secara tidak langsung cukup memantik A.W. Syarbaini untuk

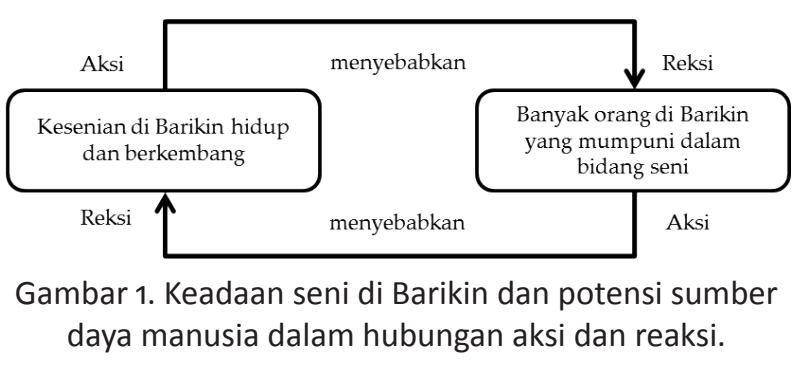


bergerak dan membuat sesuatu yang berbeda. Awalnya ia hanya mengambil iringan musik japin gunung lalu menyajikannya dalam konteks yang baru, yakni pada bagian awal sebelum mulainya suatu pertunjukan inti, yang kemudian dikenal oleh masyarakat lokal dengan sebutan banyanyanyian. Sajian musik japin gunung atau banyanyanyian, dalam perjalannya, ditambah dengan materimateri dari zikir simak, maulid tarbang ampat, dan bagandut, hingga pada akhirnya memunculkan sebuah sajian pertunjukan baru, yang kemudian dinamai musik Panting. Sajian baru yang dipelopori ini kemudian diterima dengan tangan terbuka oleh masyarakat. Setidaknya ada satu alasan utama yang menyebabkan diterimanya musik Panting dalam masyarakat Desa Barikin karena musik ini masih berada dalam kerangka budaya masyarakat setempat, yakni budaya Melayu, dan tidak berbeda secara radikal dari kesenian-kesenian lokal terdahulu.

Masih menggunakan kerangka pikir aksi dan reaksi, musik Panting dapat dilihat sebagai hasil reaksi A. W. Syarbaini terhadap kesenian-kesenian yang lebih dulu ada, yakni mulai dari japin gunung, zikir simak, maulid tarbang ampat hingga bagandut. Dengan kata lain, kemunculan musik Panting merupakan hasil laku kreatif pelopornya dalam merespon atau bereaksi terhadap apa yang sudah ada, yakni memberi sentuhan pada bentuk pertunjukan (menjadikannya sebagai sajian musik mandiri), mengambil lagu-lagu dari sejumlah sumber, dan menambah instrumentasi. Dalam konteks ini, meminjam istilah yang digunakan oleh Bruno Nettl (2015: 57), A. W. Syarbaini dapat dipandang sebagai salah satu "musicalgenius" dalam kebudayaan di Desa Barikin.

Konteks historis dan atau perjalanan waktu perlu dipertimbangkan sebab karya seni memperoleh pengaruh dari sejarah saat seni itu diciptakan. Seni memiliki karakter

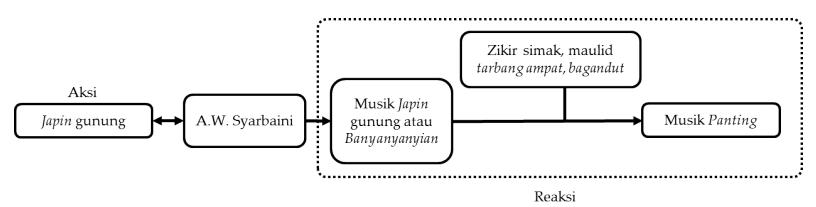

Gambar 2. Japin Gunung menjadi latar belakang munculnya musik Panting yang dipelopori oleh A. W. Syarbaini. sesuai sejarahnya dan bentuk-bentuk seni yang dipresentasikan akan berbeda-beda sesuai dengan tingkatan interaksi masyarakat pemilik kesenian dengan kondisi lingkungan sekitarnya; bagaimana kondisi eksternal mempengaruhi unsur internalnya (Hauser, 2011: 72). Hal ini menunjukkan bahwa transmisi pola-pola budaya yang berlangsung dari satu generasi ke generasi berikutnya mengalami perubahan sebagai konsekuensi perubahan masyarakat dan kebudayaan. Menurut Irawati (2016: 17), Berkaitan dengan praktik-praktik seni khususnya seni pertunjukan, perlu dicermati bahwa transmisi tidak hanya terjadi antara pemain musik dan calon pemain musik, melainkan juga antara pemain musik dengan para khalayak penonton. Artinya, dalam suatu peristiwa, tidak hanya terjadi regenerasi pemain musik, melainkan juga regenerasi penonton.

Berdasarkan uraian data di atas yang diperoleh dari penelitian, terlihat bahwa musik Panting mengalami sejumlah bentuk perubahan. Perubahanperubahan tersebut dapat dikelompokkan sebagai berikut.

\section{1) Perubahan Fungsi}

Instrumen panting pada awalnya merupakan perangkat yang digunakan untuk tujuan hiburan pribadi. Namun, dalam perjalanannya, fungsi panting berkembang menjadi hiburan masyarakat. Awalnya panting digunakan untuk mengiringi kesenian japin gunung di kalangan masyarakat pedalaman Kalimantan Selatan. Musik japin gunung seringkali disajikan secara mandiri, yakni dalam bentuk pertunjukan musik saja tanpa tarian,

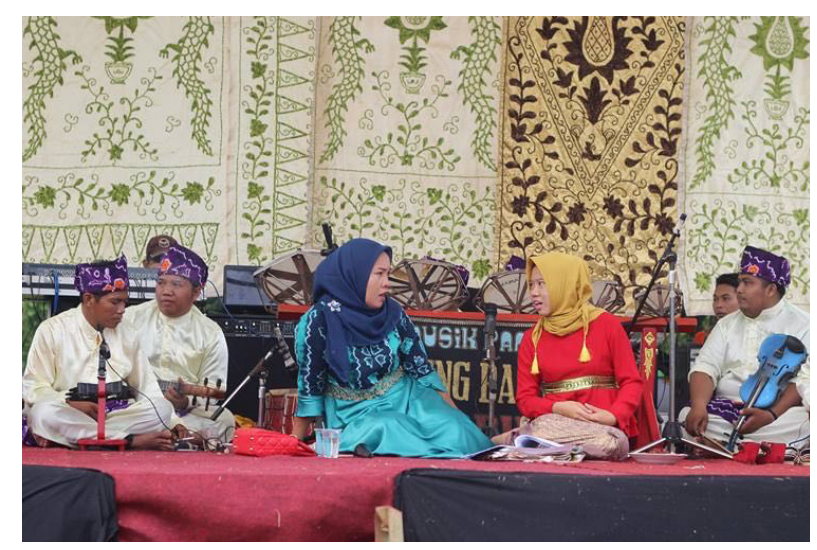

Gambar 3. Kelompok Musik Panting Ading Bastari dari Desa Barikin. (Foto: Lupi Anderiani, 2016) 
sebagai hiburan sekaligus pembuka sebelum acara inti dimulai. Dalam bentuk ini, masyarakat setempat menyebutnya banyanyanyian. Selain itu, sekitar tahun 1970-an musik ini juga digunakan sebagai iringan tari tradisi Melayu.

Minimnya sarana hiburan di tengah masyarakat yang berkembang dan dinamis merupakan salah satu penyebab hiburan musik japin begitu diminati oleh masyarakat. Selain itu, mereka memang belum pernah menyaksikan sajian ini sebelumnya. Setelah diterima oleh masyarakat, panting berkembang menjadi sebuah ansambel musik yang kemudian dinamakan musik Panting. Awalnya, musik Panting hanya digunakan sebagai sajian hiburan dalam acara-acara perkawinan saja. Namun, setelah berkembang di tengah masyarakat, musik ini juga diminati sebagai hiburan dalam kegiatan resmi di kalangan para pejabat Kalimantan Selatan. Setidaknya, ini memperlihatkan berkembangnya kelompok sosial (yang tadinya masyarakat biasa ke pejabat dan lingkungan formal) yang menaruh minat pada musik Panting.

\section{2) Perubahan Bentuk Penyajian}

Pada tahun 1985, musik Panting disajikan dalam bentuk yang terbilang sederhana, terutama dalam segi peralatan, kostum, dan jumlah lagu yang dibawakan. Semakin meningkatnya pendidikan di kalangan masyarakat menyebabkan referensi mereka terkait dunia hiburan semakin bertambah, sehingga tuntutan mereka terhadap sarana hiburan pun semakin bertambah pula. Ini mendorong para seniman musik Panting untuk terus memberikan sentuhan perubahan pada kesenian yang mereka usung agar tetap diminati oleh masyarakat dan tidak terlindas oleh bentuk-bentuk kesenian lain, yang mungkin lebih mutakhir atau modern. Salah satu reaksi terhadap tuntutan itu adalah mengubah kemasan, menyajikan musik Panting dalam bentuk sajian baru.

Musik Panting yang pada awalnya disajikan dalam bentuk "tradisional" mulai didukung dengan penggunaan perangkat sound system, kostum para penampilnya yang seragam, dan semakin banyaknya perbendaharaan lagu. Bahkan, sajian musik Panting dalam perkembangannya juga ada yang berbentuk kolaborasi dengan instrumen musik Barat, misalnya gitar, gitar bass, keyboard, dan instrumen lain. Selain itu, ada juga sajian musik Panting versi dangdut. Tempat penyajian musik Panting juga mengalami perubahan; yang tadinya hanya disajikan di panggung terbuka dalam acara perkawinan, dalam perjalanannya juga disajikan dalam ruangan tertutup atau gedung, baik dalam acara perkawinan maupun acara resmi pemerintah yang dihadiri pejabat, misalnya penyambutan tamu dari luar daerah, acara peresmian, dan sebagainya.

\section{3) Perubahan Pola Transmisi}

Pada tahun 1985, musik Panting disajikan dalam bentuk yang terbilang sederhana, terutama dalam segi peralatan, kostum, dan jumlah lagu yang dibawakan. Semakin meningkatnya pendidikan di kalangan

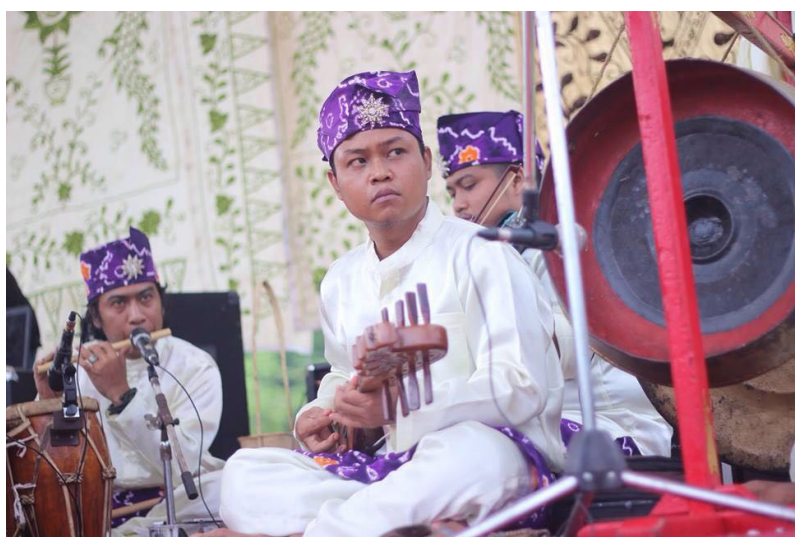

Gambar 5. Instrumen suling dan Panting dalam kelompok Ading Bastari. (Foto: Lupi Anderiani, 2016) 
masyarakat menyebabkan referensi mereka terkait dunia hiburan semakin bertambah, sehingga tuntutan mereka terhadap sarana hiburan pun semakin bertambah pula. Ini mendorong para seniman musik Panting untuk terus memberikan sentuhan perubahan pada kesenian yang mereka usung agar tetap diminati oleh masyarakat dan tidak terlindas oleh bentuk-bentuk kesenian lain, yang mungkin lebih mutakhir atau modern. Salah satu reaksi terhadap tuntutan itu adalah mengubah kemasan, menyajikan musik Panting dalam bentuk sajian baru.

Musik Panting yang pada awalnya disajikan dalam bentuk "tradisional" mulai didukung dengan penggunaan perangkat sound system, kostum para penampilnya yang seragam, dan semakin banyaknya perbendaharaan lagu. Bahkan, sajian musik Panting dalam perkembangannya juga ada yang berbentuk kolaborasi dengan instrumen musik Barat, misalnya gitar, gitar bass, keyboard, dan instrumen lain. Selain itu, ada juga sajian musik Panting versi dangdut. Tempat penyajian musik Panting juga mengalami perubahan; yang tadinya hanya disajikan di panggung terbuka dalam acara perkawinan, dalam perjalanannya juga disajikan dalam ruangan tertutup atau gedung, baik dalam acara perkawinan maupun acara resmi pemerintah yang dihadiri pejabat, misalnya penyambutan tamu dari luar daerah, acara peresmian, dan sebagainya.

\section{Penutup}

Sebagai salah satu hasil kebudayaan, musik Panting juga mengalami fase kemunculan dan juga perubahan dalam keberlangsungannya. Ini sejalan dengan sifat kebudayaan yang dinamis dan adaptatif. Penelitian ini memperlihatkan bahwa suatu hasil kebudayaan bisa muncul sebagai respon atau reaksi terhadap keadaan yang ada. Hasil-hasil budaya yang sudah ada menjadi pemicu sekaligus benih terjadinya sebuah laku kreatif. Pada gilirannya, laku kreatif ini menghasilkan suatu bentuk yang baru. Sebagai salah satu tokoh seni di Desa Barikin, A.
W . Syarbaini merespon japin gunung, mengambil iringannya dan meletakkannya dalam konteks yang berbeda, serta memasukkan elemen-elemen dari kesenian lain, yakni zikir simak, maulid tarbang ampat, dan bagandut, hingga muncullah sajian musik yang kemudian dinamakan dengan musik Panting.

Dalam perjalanannya, musik Panting tidak bisa mengelak dari perubahan. Sejak awal kemunculannya hingga saat ini, musik Pantingantara lain mengalami perubahan dalam hal berikut ini: (1) Fungsi musik, yang tadinya merupakan hiburan pribadi, kemudian menjadi hiburan masyarakat. Selain itu, kelompok atau kelas sosial peminatnya juga mengalami perubahan, yang tadinya hanya di kalangan masyarakat, kini merambah diminati dalam acara-acara resmi yang dihadiri pejabat. (2) Bentuk penyajian, yakni dalam hal penggunaan sound system, kostum yang mulai menggunakan seragam, dan perbendaharaan lagu yang semakin banyak. (3) Kontruksi instrumen panting, yakni digantinya penutup resonator yang tadinya kulit dengan kayu tipis dan dibuatnya panting elektrik. (4) Pola transmisi, yang tadinya transmisi hanya terjadi secara langsung lewat pertunjukan (live) dan wilayah cakupannya terbatas, kini bisa diakses secara global melalui media digital virtual atau maya; dan transmisi yang tadinya terjadi di lingkungan masyarakat secara informal, kini juga ditransmisikan ke sekolah-sekolah dalam bentuk pembelajaran formal. Perubahan-perubahan ini terutama terjadi karena inisiatif dari para pelakunya dalam merespon keadaan masyarakat dan dinamika kebudayaan dan penerimaan masyarakat terhadap kemunculan dan perubahan musik ini, karena pada dasarnya musik Panting masih sangat kental mengusung elemen-elemen budaya masyarakatnya, yaitu Melayu.

\section{Kepustakaan}

Hauser, Arnold. (2011). The Sociology of Art. London \& New York: Rouledge.

Irawan, Andre. (2010). "Selawatan sebagai Seni Pertunjukan Musikal." Resital Jurnal Seni Pertunjukan Vol. 11, No. 2, Desember: 95- 
105.

Irawati, Eli. (2013). Eksistensi Tingkilan Kutai

Suatu Tinjauan Etnomusikologis. Yogyakarta:

Kaukaba Dipantara.

Irawati, Eli. (2016). "Transmisi Kelentangan dalam

Masyarakat Dayak Benuaq." Resital Jurnal

Seni Pertunjukan Vol. 17, No. 1, April: 1-25.

Maman, Mukhlis, dkk. (2006). Topeng Banjar di

Barikin. Banjarmasin: UPTD Taman Budaya

Provinsi Kalimantan Selatan.

Nettl, B. (2015). The Study of Ethnomusicology: Thirty-

Three Discussions. Urbana: University of Illinois Press.

Radam, N. H. (2001). Religi Orang Bukit.

Yogyakarta: Penerbit Yayasan Semesta.

Saleh, M. I. (1981/82. Banjarmasih. Banjarmasin:

Proyek Pengembangan Permuseuman

Kalimantan Selatan.

Sanderta, Bakhtiar, dkk. (2000). Pantun Madihin

Lamut. Banjarmasin: Dinas Pendidikan dan

Kebudayaan Tingkat I dan Dewan Kesenian

Kalimantan Selatan.

Satriana, Rasita, Timbul Haryono \& Sri Hastanto.

(2014). "Kanca Indihiang sebagai Embrio

Kreativitas Mang Koko". Resital Jurnal Seni

Pertunjukan Vol. 15, No. 1, Juni: 32-42.

\section{Informan}

A. W. Syarbaini. Pegawai Negeri Sipil, Tokoh Seniman Panting, 1955-2016, Desa Barikin, Kecamatan Haruyan, Kabupaten Hulu Sungai Tengah, Kalimantan Selatan.

Bakhtiar Sanderta. Pensiunan Pegawai Negeri Sipil (Taman Budaya), Tokoh Seni dan Budayawan Kalimantan Selatan, 65-an tahun, Kayu Tangi II Banjarmasin, Kalimantan Selatan.

Iyus. Swasta, Pimpinan Kelompok Musik Panting Moneca, 43 tahun, Desa Masimpan, Kecamatan Telaga Langsat, Kabupaten Hulu Sungai Selatan, Kalimantan Selatan.

Romeo. Swasta, Pimpinan Kelompok Musik Panting Pandan Sari, 39 Tahun, Desa Tabat Padang, Kecamatan Haruyan, Kabupaten Hulu Sungai Tengah, Kalimantan Selatan.

M. Aini. Pegawai Negeri Sipil, Seniman dan Pencipta Lagu Musik Panting, 43 tahun, Desa Barikin, Kecamatan Haruyan, Kabupaten Hulu Sungai Tengah, Kalimantan Selatan.

A. Riadi. Pensiunan Pegawai Negeri Sipil, Seniman Gandut, 60-an tahun, Desa Bungur, Kecamatan Bungur, Kabupaten Tapin, Kalimantan Selatan. 